\title{
Substantial Position of Constitution as Human Nature to the Existence of State in Modern Civilization
}

\author{
Syafruddin Muhtamar ${ }^{1} \quad$ Muhammad Ashri $^{2} \quad$ M. Arfin Hamid ${ }^{2} \quad$ Zulkifli Aspan ${ }^{2}$ \\ 1.PhD Student at Postgraduate Program, Faculty of Law, Hasanuddin University \\ 2.Professors on Legal Science, Faculty of Law, Hasanuddin University
}

\begin{abstract}
The existence of constitution is closely related to political life and institutions of state power. It is the nature of human life. A tendency to put the foundation of political life and law above the highest righteousness as the "Basic Law", a reflection of human nature; wants to rely on the highest righteousness in norms, both religious (medieval constitutionalism phenomenon) and legal (modern century constitutionalism phenomenon). Constitution as a state philosophy reflects virtue as the foundation of state philosophy.
\end{abstract}

Keywords: Constitution, Nature, Basic Law, State Philosophy

DOI: $10.7176 / \mathrm{JLPG} / 82-12$

\section{Introduction}

History of constitution in the historical phase of civilization is geographically divided into two, namely Western and Eastern civilization. Western civilization is represented in the history of ancient Greek and Roman, Europe and Modern America civilizations. While Eastern civilization is in the history of Islamic civilization, classical archipelago and modern Indonesia.

Following the historical logic built by Jimly Assidiqie when mapping the constitution history in relation to constitutionalism (Jimly Assidiqie, 2010), then the flow of constitution history and the idea of constitutionalism began from the era and heritage of ancient Greek, with particular attention to the works of Plato and Aristotle in The Law (Nomoi) and Politics. The next phase is Cicero's heritage in the Ancient Roman era, with his work as the main source, namely De Re Publika. Furthermore, the Mecca era with its Madina Charter of Muhammad SAW as the key marker of a classical constitution. Then, entering the era of modern constitution in Europe and America in the 16 th to 18 th century.

One of the fundamental dimensions of constitutional historicity is the term regarding the constitution itself. Constitution as a terminology has a long history within the scope of Law, and specifically in the field of Constitutional Law. This means that the term constitution used in this modern century has a connection with several terms that existed in the past, even though the terms varied. If it is compiled, there are several terms that have equal meaning with the term constitution used in the latest era and terms used in the past.

Those terms among others are: politeia, constitution, jus, constitution, the acts of legislation by the Emperor, aviate constitutions or leges, a recordation vel recognition, lex, edictum (secular administrative enactments), a royal edict, magna charta (contitutio libertatis), the remedy innovel disseisin (une nouvele contitucion), status reipublicae and piagam madina.

\section{Modern Function of Constitution as Basic Law}

Adjusting to the context of modern history, the concept of relevant law is a concept that contains the spirit of positivism. In this case, the definition of law according to Hans Kelsen is: law is an order of human action. "Order" is a system of rule. Law is a set of rules that contains a set of unity that we understand through a system. Law is always a positive law, and legal positivism lies in the fact that the law is created and abolished by human action, regardless of morality and systems of norm themselves. Law is the dynamic system of a state (Hans Kelsen, 2015).

Law as a system, and the basis of people's life is realized due to the existence of state as a form of law. This is a modern history phenomenon regarding the existence of modern state in connection with legal system. State has an interest to order, and is considered as the basic task of a state. Both in the context of classical and modern state theory, a postulation that a state has activities to organize or revive order is always relevant in relation to the essential function of an organizations of community power. As pointed out by Mac Iver: law and order according to tradition are always associated, and we can see order as fairly essential in the state activities. Obtaining an absolute order within the boundaries of the environment is the most important thing that it (the state) can do, and this has always been a very special task of the state. This is also strongly emphasized by democracy and despotism, by empire and federation (Mac Iver 1988).

Referring to the definition of basic law as a guide in the administration of state (Jimly 2010); as a direction for how the government has the authority to organize the implementation of state power (I Dewa Gede Atmaja 2014); and as a degree of constitutional supremacy where it is in the highest position in the legal order of state (Dahlan Thaib, et.all. 2004), then the term basic law can be understood as a functional derivation of the scope dimension of constitution concept. 
Classical government identifies itself as the ruler of all nature's representative chosen by gods, goddesses or God. The applicable law is what "the ruler of all nature" wants. The legal order received is derived from the will of God or gods and goddesses, not the will of the ruler or the people, so the basis of the applicable legal system lies in moral values and scripture. As Carl Joachim Friedrich said, Nomos was originally a custom of sacred habits, which was applied and assumed to be true in polis (Ancient Greek city-state). This rule covers everything. Pindar poet said that nomos basileus pantom is the law of sacred custom which is the determinant of everything (Carl Joachim Friedrich, 2010).

According to Greek thinkers, nomos (commonly translated as Law) is the source of all laws in the essence of its broadest meaning. Nomos is a general rule in the same form for all people in an effort to pursue justice, beauty and expediency. In addition, nomos is customary and law: it covers the entire applicable legal rules (John Gilissen and Frits Gorle, 2011).

A more perfect understanding of basic law is found in the history of modern government because its nature, character, and elements correspond to the essence of basic law understanding. The concept of basic law is actually rooted and reflected in the reality of rationalism as the nature of modern order, it has positivist character and empirical elements, so the concept of basic law with the same spirit can be understood.

Constitution is a basic law, as mentioned by Jimly Assidiqie, it is used as a guide in the administration of state. Basic law can be in the form of Constitution (written basic law), and unwritten basic law. Therefore, Constitution as a written basic law along with the unwritten basic legal values and norms that lives as a constitutional convention in the practice of day-to-day state administration is included in the definition of a constitution or basic law (droit constitusionnel) of a state (Jimly Assidiqie 2010). Based on this argument, the substance of basic law includes both written and unwritten. In fact, written constitution is discovered massively in the modern age, while in the classical century, constitution was generally found as a customary practice.

\section{Inevitability of Modern State Relation to Constitutionalism Idea}

One time Kant said that a group of demons could get or create a state, "on the grounds that they have sensitivity about it according to their needs" (Carl Schmitt, in Wael B. Hallaq 2015). Kant's argument, captured by a notion that organization (state) is a human need because it is a natural need, even though a group of demons can do it because they have a need for it.

If it starts from 'human needs', it is assumed that the age of 'state' has the same age as the existence of human history. Because the 'needs' is a part of soul that has existed along with the existence of humans in life. The meaning of 'state' as a 'human need' reflects a thought explaining that: naturally, there are basic needs in the soul, about the urgency of social life through organization for the ideal goal desired by humans.

The description of the reality of a modern state existence can be seen in the description by Jimly Assidiqie: when nation states hold a very strong, centralized and very powerful form during the 16th and 17th centuries, various political theories develop to provide an explanation of the development of this robust power system. In England in the 18th century, the development of centralism took its form in the king-in-parliament doctrine, which basically reflected the unlimited power of the king, as Richard S. Kay said: "By 1776 Blackstone was able to write that what Parliament does "no authority upon eart can undo". It was party in response to the positing of leviathanstate that the idea of a government of limited purpose, and therefore of limited power, was reformulated and explicated." Because of this, constitutionalism at the present time is considered a necessary concept for every modern state. As stated by C.J. Friedrich: "constitutionalism is an institutionalized system of effective, regularized restraints upon government action".

The meaning of this historical fact is that a state and its power often reveals its dangerous form for humanity and life, specifically when the ruler through the state forces 'absolute' authority, or what is commonly known as 'the leviathan state' (Oswaldo de Rivero 2008). From this phenomenon, modern constitutionalism emerged as a strong new demand, then it became the ideal model for states of the modern era. The term state-constitutionalism can be said to arise from such analysis model. An understanding that put the state authority with rational boundaries using legal norms and put it at the highest position in the hierarchy of regulations with the power of supremacy. Constitutionalism is an idea that contains great hopes for modern society in realizing the ideal hope of human through modern state political organizations.

The phenomenon of society political life in the history shows that politics universally exists in all groups of society, said Stephen K. Sanderson, because the society has various ways of social control and decision making that vary from one society to another (Stephen K. Sanderson 1993). One form of political mechanism according to Sanderson is power: power is an important element in most political systems. By slightly changing its classical definition by Max Weber (1978, originally 1923), power can be formulated as the ability to control the behavior of others, or even put the efforts against it. Power contains the element of ability to overcome resistance and ensure the wish of the power holders. Behind power there are constant threats, coercion or force when there are orders or decisions that are not obeyed voluntarily.

In organizing political life, humans use power as a tool to strengthen the power of the ruler itself, because the 
element of coercion in power is dominantly used to demand compliance of people in the territory. It can be understood when Lord Acton mentions: "power tends to corrupt, but absolute power corrupts absolutely" (Lord Acton in Syafnil Efendi, 2011).

The practice of community or state leadership that reveals the nature of 'destructive' power is the real reason why logically power must be given limitations through law, especially in the modern century. It is evident from the growing constitutionalism idea in the modern age, especially since the 18th and 19th centuries. As is known, the term constitutionalism emerged at the turn of the 18th century to the 19th century to assert the American doctrine about supremacy of the Constitution (written constitution) above legislation promulgated as a product of the legislature.

Constitutionalism emerged due to the fact that the implementation of authoritative government in a state deviates from ideals. In the modern age, a state is a community organization whose existence is absolute, with evidence that in the recent centuries, there is no individual who is not a member of a state, and also the fact that there is no geographical area that is free from a state' jurisdictional boundaries claim on this planet.

\section{Functional Reflection of Constitution as State Philosophy}

According to Aristotle, all associations have a goal: political association has the highest goal; but the principle of association expresses itself in different forms, and through different ways of governance (Aristoteles 1995). The term association refers to the ancient history of Greece concerning polis or city-state. It also becomes an evidence of the existence of a community organization that is motivated by objectives with certain principles which, in Aristotle's record, the phenomenon is shown by different governmental units from each community.

This means that the existence of political community organization (state) throughout the history of human civilization has always been intended for good virtues. Virtue is an abstract value in the form of idea, doctrine, or norm that contains truth: mythical, religious and rational. To make the purpose of virtue a link that connect shared life in a state system, this virtue is institutionalized in the constitutional juridical formulation. Constitution is a place where state philosophy can be found, in the history of modern state.

Modern history clearly shows that constitution serves as a state philosophy. The content of constitution material is the result of reflection of thought containing the depth of philosophical value within its objective boundaries, and it becomes the key value that is realized for the ideal purpose in the content of constitution material. In the context of such thinking, the position of constitution becomes the soul of the state organization itself, and it is called the state philosophy.

The state philosophy is generally closer to the terminology of political science which is called political ideology. It is a belief made by human as a way and guidance to carry out the political or state activities. Andrew Heywood describes political ideology as follows: among the definitions of ideology, it is described as a system of political beliefs, an action-oriented device of political ideas, a set of ideas held by the ruling class, and a set of ideas that are officially adopted and can impose sanctions to legitimize a political system or regime (Andrew Heywood 2016).

Conceptually, there is a connection between the meaning of state philosophy and political ideology. The substantive position of the modern constitution as a state philosophy can be said to be a 'natural' permanent position. It is natural for a state constitution to be a philosophy or ideology, because in constitution lies the beliefs, hopes and ways on how the institutional power is carried out to obtain the ideal goals of humans. Constitution is also in this position, and it is considered as 'the book of life' for humans through government activities.

This fact can be reinforced by Max Weber's analysis on types of authority in social organization. Weber identified three basic legitimacy basis in an authority (Max Weber in Doyle Paul Johnson, 1986): First, traditional authority, second, charismatic authority, and third, legal-rational authority. These three Weber types can be used to find out and identify typology of values used by humans in the history of social organizations or states.

Constitution as a state philosophy is correlative, not functionally separated. Because social organizations and states had existed throughout the history of human civilization, constitutionalism has also become an idea that always accompanying throughout the history. Organization or state is human consciousness so that constitution is also part of fundamental human consciousness.

Jimly Assidiqie said that state is constitutional, therefore state consciousness must be developed along with constitutional awareness. All aspects of policies and practices of state activities must be linked to the issues of constitutionality as the peak of our mutual agreement as a nation namely state at the modern time today. Of course, what we mean by constitution is not just the formulation of text. There are ideas behind each of these words, and every idea certainly contains the content of fundamental values and principles. It is the soul or spirit contained in every formulation of norm in the constitution. Norms with the constitution formulation inside are not only in the form of legal norms but also principal ethical norms. Therefore, constitution must always be understood deeply (Jimly Assidiqie 2014). 


\section{Conclusion}

The constitutional position plays a vital role in the history of legal and political life of modern human civilization. It has been existed since $\mathrm{BC}$ and $\mathrm{AD}$ century, both in Western and Eastern civilizations. Historical facts show that the existence of constitution is not separated from political life, institutions of state power, and law in human civilization. Thus, it can be said that constitution (as a basic law and state philosophy), being a member of a state and following laws in fundamental principles are the nature of human life itself.

\section{References}

Jimly Assidiqie, (2010), "Konstitusi dan Konstitusionalisme Indonesia”, Sinar Grafika, Jakarta.

Hans Kelsen, (2015), “Teori Umum tentang Hukum dan Negara”, Nusa Media, Bandung.

Mac Iver, (1988), "Negara Modern”, 1988, Bina Aksara, Jakarta.

I Dewa Gede Atmaja, (2014), "Filsafat Ilmu: dari Pohon Pengetahuan sampai Karakter Keilmuan Ilmu Hukum", Madani, Malang.

Dahlan Thaib, Dkk. (2014), “Teori Hukum dan Konstitusi” Raja Grasindo Persada, Jakarta.

Carl Joachim Friedrich, (2010), "Filsafat Hukum Persepktif Historis", Nusa Media, Bandung.

John Gilissen dan Frits Gorle, (2011), "Sejarah Hukum; Suatu Pengantar”, Refika-Aditama, Bandung.

Wael B. Hallaq, (2015), “Ancaman Paradigma Negara-Bangsa (Islam, Politik, dan Problem Moral Modernitas)”, Suka Press, Yogyakarta.

Oswaldo de Rivero, (2008), "Mitos Perkembangan Negara: Perekonomian Negara yang Tidak Memiliki Kemampuan untuk Berkembang di abad 21", Pustaka Pelajar, Yogyakarta.

Stephen K. Sanderson, (1993), "Sosiologi Makro", Raja Grafindo, Jakarta.

Syafnil Efendi, (2011), "Konstitusionalisme dan Konstitusi Ditinjau dalam Perspektif Sejarah", Jurnal Humanus, Vo. X, No. 1, Tahun 2011, 73-81.

Aristoteles, (1995), "Politic", Narasi, Yogyakarta.

Andrew Heywood, (2016), "Ideologi Politik; Sebuah Pengantar”, Pustaka Pelajar, Yogyakarta.

Doyle Paul Johnson, (1986), “Teori Sosiologi Klasik dan Modern”, Gramedia, Jakarta.

Jimly Assidiqie, (2014), "Gagasan Konstitusi Sosial; Institusionalisasi dan Konstitusionalisasi Kehidupan Sosial Masyarakat Madani”, LP3ES, Jakarta. 